\title{
Prevalence of Salmonella contamination in processing chain of selected chicken- based side dishes
}

\author{
${ }^{1}$ Novera, R., ${ }^{2,3}$ Rahayu, W.P., ${ }^{2,3 *}$ Kusumaningrum, H.D., ${ }^{4}$ Indrotristanto, N. and \\ ${ }^{4}$ Nikastri, E. \\ ${ }^{1}$ Food Science Study Program, IPB University, PO BOX 220, Bogor 16002 Indonesia \\ ${ }^{2}$ Department of Food Science and Technology, IPB University, PO BOX 220, Bogor 16002 Indonesia \\ ${ }^{3}$ SEAFAST Center, IPB University, Kampus IPB Darmaga, Bogor 16680 Indonesia \\ ${ }^{4}$ National Agency of Drug and Food Control, Jl. Percetakan Negara 23 Jakarta 10560 Indonesia
}

\section{Article history:}

Received: 13 October 2019

Received in revised form: 11

December 2019

Accepted: 14 December 2019

Available Online: 17 January 2020

Keywords:

Salmonella spp.,

Chicken-based side dishes,

Most probable number

(MPN),

School canteen

DOI:

https://doi.org/10.26656/fr.2017.4(3).338

\begin{abstract}
This study was aimed to determine the prevalence, the level and the main contributing factors to contamination of Salmonella spp. in four selected chicken-based side dishes prepared for the school canteens. One hundred and seven samples were collected from four different food processing chains, i.e. fried chicken with precooking, fried chicken without precooking, breaded fried chicken, and sauced chicken. Salmonella contamination was determined by the most probable number (MPN) and confirmed with polymerase chain reaction. Salmonella spp. were detected in 8 of 21 chicken cuts samples (360-920 $\mathrm{MPN} / \mathrm{g})$ and in 4 of 30 end products samples (0.61-3 MPN/g). The fact that Salmonella was still found at the end product indicated that cross-contamination and/or inadequate heating process likely occurred. Besides the chicken cuts, the contributing factors to the Salmonella contamination were water (4 of 17 samples) and seasonings (8 of 13 samples). To ensure the safety of chicken-based side dishes prepared for the school canteen, adequate cooking process must be performed by all food handlers. The results of this study might contribute to analysing the risk of salmonellosis in Indonesia.
\end{abstract}

\section{Introduction}

Poultry and its products are among the most nutritious food, but also a well-known reservoir of Salmonella spp. (Gould et al., 2013; Kang et al., 2017). Salmonella spp. is a very adaptive microorganism, which can cause human salmonellosis, an important foodborne disease (Giaouris and Nychas, 2006). In Indonesia, not many Salmonella spp. cases have been reported. A report from Chusniati et al. (2009) stated that domestic chicken eggs used in a traditional herbal drink (jamu) in Sidoardjo City, East Java of Indonesia, were contaminated by Salmonella spp. (5.56\% from 36 samples). In 2011, the microbial examination conducted on 4808 food samples from the school canteens revealed that $13(0.27 \%)$ samples contaminated by Salmonella (NADFC, 2012). In 2016 NAFDC examined 106 fried chicken samples using the Most Probable Number (MPN) method and confirmed by Polymerase Chain Reaction (PCR) method, found that 45 samples were contaminated by Salmonella spp. with $42.0 \%$ of prevalence, and $0.36-2.30 \mathrm{MPN} / \mathrm{g}$ of concentration (NADFC, 2016a). In 2017 NADFC reported 53 foodborne outbreaks in Indonesia, where 2041 people ill and 3 people died. About $13.21 \%$ of the outbreaks confirmed as microbial related, and 15 outbreaks $(28.30 \%)$ happened in school (NADFC, 2017).

Salmonella on food has to be negative (NADFC, 2016b), but diseases related to Salmonella are still be found although not always foodborne related. Many studies showed that poultry or its products are the sources of Salmonella contamination. Barua et al. (2014) studied the sources of non-typhoidal Salmonella enterica serovars in human and found that nine serovars of Salmonella were isolated from human stool samples, and it's commonly found on poultry. Since 1981 the outbreaks related to salmonellosis had been reported by Cobet et al. (1981) who isolated 158 Salmonella Oranienburg from 150 hospitalized patients with diarrhoea. Punjabi et al. (2013) reported 296 laboratoryconfirmed enteric fever cases during the 7 months surveillance period in North Jakarta Indonesia, of which $221(75 \%)$ were typhoid fever and $75(25 \%)$ were the paratyphoid fever. Most of the cases occurred among children under five years old.

Chicken is one of the most popular food products in 
Indonesia. High level of protein and low-fat content contributed to the popularity of chicken. Furthermore, chicken is easy to prepare and widely used in restaurants, cafes, or canteens as a main meal or side dishes. Foods at the school canteens contributed to $15-20 \%$ of daily nutrition for the students. Most of the students (98.9\%) who did not have breakfast will eat at the canteen. Those foods gave $31.06 \%$ of energy and $27.44 \%$ of protein every day (NADFC, 2012). Chicken based side dishes is a common food found in the school's canteen in Indonesia. This food has a risk of being contaminated by Salmonella. It is very important to ensure food safety at school considering the fact that the children are the future of the nation. Considering the severity and risk level of Salmonella and the regulation stated by NADFC (NADFC, 2012), the study of Salmonella contamination in chicken-based side dishes in school canteen is very important. This study aimed to identify the prevalence, the level, and the sources of Salmonella spp. contamination in selected chicken-based side dishes in the school's canteen.

\section{Materials and methods}

The chicken-based side dishes samples were collected from nine merchants of eight school canteens, namely fried chicken with precooking, fried chicken without precooking, breaded fried chicken, and sauced chicken. A total of 107 samples was collected, consisted of raw materials (chicken cuts, seasoning, egg, and water), precooked chicken, final product, swab sample from the hand of food handlers, and cutting boards.

\subsection{Enumeration of Salmonella spp.}

The enumeration method was conducted according to Pavic et al. (2009). A total of $25 \mathrm{~g}$ of samples were put into $225 \mathrm{~mL}$ of Buffer Peptone Water (BPW, Oxoid, UK) in stomacher bag and homogenized by stomacher (Seward $^{\mathrm{TM}}$ Stomacher ${ }^{\mathrm{TM}}$ Model 400C Circulator Lab Blender, Fisher Scientific, USA) for 2 mins. A total of $10 \mathrm{~mL}$ of the initial suspension was transferred into each of 3 tubes containing $10 \mathrm{~mL}$ of BPW (double strength). An aliquot of the initial suspension was transferred into each of 3 tubes containing $9 \mathrm{~mL}$ of single strength BPW. Next, the initial suspension was diluted in BPW to provide $10^{-2}$, and $1 \mathrm{~mL}$ was transferred to each of $3 \times 9$ $\mathrm{mL}$ of BPW. All the tubes were incubated at $37^{\circ} \mathrm{C}$ for 24 hrs and observed for the turbidity.

A $100 \mu \mathrm{L}$ of the positive tubes were transferred into a petri dish containing Modified Semi-Solid RappaportVassiliadis Agar (MSRVA, Oxoid, UK) and incubated at $42^{\circ} \mathrm{C}$. White colonies were observed after 24 and $48 \mathrm{~h}$ of incubation. The white colony was then subcultured on Xylose Lysine Deoxycholate Agar (XLDA, Oxoid, UK) and incubated at $37^{\circ} \mathrm{C}$ for $24 \mathrm{hrs}$ A single colony from specific colonies (red with or without black globule in the middle) was inoculated on Brain Heart Infusion Agar (BHIA, Oxoid, UK) medium and incubated at $37^{\circ} \mathrm{C}$ for 24 hrs. Salmonella enterica serovar Typhimurium ATCC 14028 and E. coli ATCC 25922 were used as positive and negative controls.

\subsection{Confirmation of Salmonella by PCR method}

PCR method was conducted according to Rahn et al. (1992) with modification. One loop colony from BHIA was transferred into $500 \mu \mathrm{L}$ of sterilized $0.85 \%$ Nalco (Merck, Germany) in 1.0-1.5 mL tube, homogenized and boiled in thermomixer (Eppendorf Thermomixer $\mathrm{C}$, Germany) at $100^{\circ} \mathrm{C}$ for 15 mins, then kept at $-20^{\circ} \mathrm{C}$ for 2 mins as a cold shock treatment. Then centrifuged (Hettich Zentrifugen Universal $320 \mathrm{R}$, Germany) at $12000 \mathrm{rpm}$ for 5 mins. The DNA template was pipetted from the supernatant and transfer into $500 \mu \mathrm{L}$ of sterilized microcentrifuge tubes.

PCR reaction $(25 \mu \mathrm{L})$ using Go Taq Green Master Mix (Promega, US) kit with a composition of $2.5 \mu \mathrm{L}$ DNA template from previous step, $0.5 \mu \mathrm{L}$ each from forward and reversed primer which was F139 5'GTGAAATTATCGCCACGTTCGGGCAA-3' and R141 5'TCATCGCACCGTCAAAGGAACC3' (Macrogen, Singapore), $12.5 \mu \mathrm{L}$ Go Taq Green Master Mix, and $9 \mu \mathrm{L}$ nuclease-free water (Promega, US) were prepared. The mixture of master mix and DNA template in PCR tube was homogenized and placed into thermal cycler (PCR) machine (Blue Ray Biotech, Taiwan) according to the shown in Table 1.

Table 1. PCR protocol

\begin{tabular}{lcc}
\hline \multicolumn{1}{c}{ Steps } & Temperature $\left({ }^{\circ} \mathrm{C}\right)$ & Time (Minutes) \\
\hline Pre-denaturation & 72 & 7 \\
Denaturation & 94 & 1 \\
Annealing & 53 & $1^{*}$ \\
Elongation & 72 & $2^{* *}$ \\
Post Elongation & 72 & 7 \\
Hold & 4 & Forever \\
Cycle & 35 & \\
\hline
\end{tabular}

Reference: Rahn et al. (1992) with modification: * from 2 modified to 1 minutes; ${ }^{* *}$ from 3 modified to 2 minutes

\subsection{Detection of DNA amplification by electrophoresis}

Tris-Borate EDTA (TBE) (1st base, Singapore) solution was prepared using miliQ water. Agarose 2\% (1st base, Singapore) was prepared and 4-6 $\mu \mathrm{L}$ per 100 $\mathrm{mL}$ of flourosafe were added. The agarose was poured into the block to solidify. The remaining TBE solution was poured into the electrophoresis vessel (Biometra, Germany) then added the solid agarose. About $10 \mu \mathrm{L}$ 
from each of PCR product transferred into all the wells of agarose. Some of the wells were filled with marker (DNA ladder $100 \mathrm{bp}$ of nucleotides), non-template control (NCT), positive and negative control bacteria. Then the vessel connected with the electrical source (ampere meter), with $75 \mathrm{~V}$ for 45-60 mins. The result was observed and documented using GelDoC devices (Bio-Rad, US). The criteria for the band acceptance was $284 \mathrm{bp}$.

\section{Results and discussion}

This study found that 30 of 107 samples were contaminated by Salmonella spp., indicated by the appearance of $284 \mathrm{bp}$ band in PCR product (Figure 1). Invasive A gene (invA) was used as the target gene since it is the regulator for the invasive character. This character enabled Salmonella to penetrate the epithelium tissues of the intestine (Galán and Curtiss, 1989). A total of 4 of 30 end product samples were contaminated, but the level of contamination was significantly lower than chicken cuts (Table 2-5).

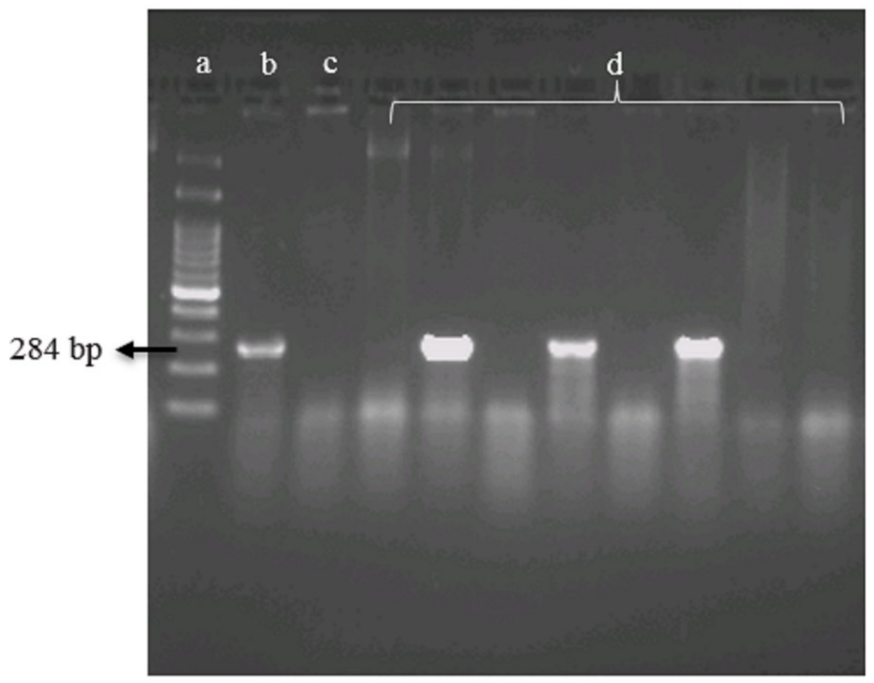

Figure 1. PCR amplification of Salmonella spp. in samples. a. Ladder, b. positive control (Salmonella enterica serovar Typhimurium ATCC 14028, c. negative control (E. coli ATCC 25922), d. DNA of samples

Table 2. Salmonella spp. contamination in the processing chain of fried chicken with precooking

\begin{tabular}{lccl}
\hline \multicolumn{1}{c}{ Samples } & $\begin{array}{c}\text { Total } \\
\text { Sample }\end{array}$ & $\begin{array}{c}\text { Positive } \\
\text { Salmonella } \text { spp. }\end{array}$ & \multicolumn{1}{c}{ Concentration } \\
\hline Chicken cuts & 6 & 3 & $360-920 \mathrm{MPN} / \mathrm{g}$ \\
Seasoning & 6 & 4 & $0.3 \mathrm{MPN} / \mathrm{g}$ \\
Water & 6 & 0 & $<0.3 \mathrm{MPN} / \mathrm{mL}$ \\
Hand & 2 & 0 & $<0.3 \mathrm{MPN} / \mathrm{Hand}$ \\
Cutting board & 1 & 0 & $<0.3 \mathrm{MPN} / 25 \mathrm{~cm}^{2}$ \\
Precooked & 6 & 0 & $<0.3 \mathrm{MPN} / \mathrm{g}$ \\
chicken & 6 & 0 & $<0.3 \mathrm{MPN} / \mathrm{g}$ \\
Fried chicken & 8 & & \\
\hline \multicolumn{1}{c}{ Total } & 35 & &
\end{tabular}

$\mathrm{t}_{\text {boiling }}=30 \mathrm{~min} ; \mathrm{T}_{\text {meat core }}=75^{\circ} \mathrm{C} ; \mathrm{t}_{\text {frying }}=13 \mathrm{~min} ; \mathrm{T}_{\text {meat }}$ core $=$ $91^{\circ} \mathrm{C}$.

eISSN: $2550-2166$
The number of contaminated end products was mainly associated with contamination in 8 of 21 (38.09\%) chicken cut samples used as raw materials. Chicken cut samples were contaminated by Salmonella spp. with a range of 300-920 MPN/g. It was lower than the report from Kholifah et al. (2016) in Samarinda City, Indonesia, but higher than Naik et al. (2015) in India and Alali et al. (2012) in Russia.

Hajrawati et al. (2016) reported that the intrinsic parameters of chicken carcasses in the Indonesian market were $0.84-0.85$ for water activity and 6.00-6.37 for $\mathrm{pH}$. This condition is suitable for Salmonella spp. which need water activity of 0.93 and $\mathrm{pH}$ of 4.5-9.0 to grow (Cary et al., 2000). El-Aziz (2013) reported that Salmonella enterica serovar Typhimurium was detected from 100 samples (each 25 frozen samples of chicken meat, liver, heart and gizzard) collected from Assiut city market, with a prevalence of $44 \%$ in chicken meat, $40 \%$ in liver, $48 \%$ in heart and none in the gizzard. The contamination on chicken cuts might occur during the slaughter process. In this study, chicken cuts and seasoning were brought from the traditional market. Maulita et al. (2017) reported that 8 of 10 samples of equipment used in the cutting process in the traditional market in Aceh, a province in Indonesia, were contaminated by Salmonella spp. with the highest concentration on the cutting board, $4.8 \times 10^{4} \mathrm{MPN} / \mathrm{g}$. A similar report came from Nidaullah et al. (2017) that found 161 Salmonella spp. isolated from 182 samples $(88.46 \%)$ consisting of chicken carcasses, cages, knives, cutting boards, water, defeathering machines, and aprons collected Malaysian traditional markets,

Two of four processing chain on the preparation of chicken-based side dishes in this study applied precooking process and was able to eliminate Salmonella spp. (Tables 2 and 5). The boiling process was conducted at $82-100^{\circ} \mathrm{C}$ for $15-20$ mins. The occurrence of Salmonella spp. in the end products may be due to crosscontamination after precooking process. The possible sources of contamination were seasoning, water, cutting board and the hand of food handlers (Table 2-5).

Two of 6 end products of sauced chicken were contaminated (Table 5). The boiled chicken of sauced chicken was chopped and stir-fried with seasoning. Salmonella spp. was recovered from the seasoning, cutting board and hand of food handlers in this process (Tables 2 and 4). Swab samples of cutting boards and the hand of food handlers were conducted before the chopping process.

Furthermore, eight of 13 seasoning samples was contaminated. The seasonings consisted of onion, garlic, turmeric, and pepper. The level of Salmonella spp. was 
in a range of 0.3-0.92 MPN/g. However, the seasoning used for fried chicken without precooking was negative for Salmonella spp. (Table 3). A report from van Doren et al. (2013) stated that Salmonella spp. could be isolated from turmeric and pepper in Canada, Denmark, England and Wales, France, Germany, New Zealand, Norway, Serbia, and the United States.

Table 3. Salmonella spp. contamination in the processing chain of fried chicken without precooking

\begin{tabular}{lccl}
\hline \multicolumn{1}{c}{ Samples } & $\begin{array}{c}\text { Total } \\
\text { Sample }\end{array}$ & $\begin{array}{c}\text { Positive } \\
\text { Salmonella } \text { spp. }\end{array}$ & Concentration \\
\hline Chicken cuts & 4 & 1 & $300 \mathrm{MPN} / \mathrm{g}$ \\
Seasoning & 2 & 0 & $<0.3 \mathrm{MPN} / \mathrm{g}$ \\
Water & 4 & 1 & $0.3 \mathrm{MPN} / \mathrm{mL}$ \\
Hand & 2 & 0 & $<0.3 \mathrm{MPN} / \mathrm{Hand}$ \\
Fried chicken & 8 & 1 & $3.0 \mathrm{MPN} / \mathrm{g}$ \\
\hline \multicolumn{4}{c}{ Total } \\
\hline $\mathrm{t}_{\text {boiling }}=30 \mathrm{~min} ; \mathrm{T}_{\text {meat core }}=78.22^{\circ} \mathrm{C}$
\end{tabular}

Table 4. Salmonella spp. contamination in the processing chain of breaded fried chicken

\begin{tabular}{lccl}
\hline \multicolumn{1}{c}{ Samples } & $\begin{array}{c}\text { Total } \\
\text { Sample }\end{array}$ & $\begin{array}{c}\text { Positive } \\
\text { Salmonella } \text { spp. }\end{array}$ & Concentration \\
\hline Chicken cuts & 8 & 2 & $300-740 \mathrm{MPN} / \mathrm{g}$ \\
$\begin{array}{l}\text { Seasoning } \\
\text { Water }\end{array}$ & 4 & 2 & $0.3 \mathrm{MPN} / \mathrm{mL}$ \\
$\begin{array}{l}\text { Hand } \\
\begin{array}{l}\text { Breaded Fried } \\
\text { chicken }\end{array}\end{array}$ & 2 & 2 & $0.92 \mathrm{MPN} / \mathrm{g}$ \\
\hline
\end{tabular}

$\frac{\text { Total }}{\mathrm{t}_{\text {boiling }}=6 \text { min; } \mathrm{T}_{\text {meat core }}=86.38^{\circ} \mathrm{C}}$

Table 5. Salmonella spp. contamination in the processing chain of sauced chicken

\begin{tabular}{lccl}
\hline \multicolumn{1}{c}{ Samples } & Total & Positive & \multicolumn{1}{c}{ Concentration } \\
\hline Chicken cuts & 3 & 2 & $360-720 \mathrm{MPN} / \mathrm{g}$ \\
Water & 3 & 1 & $0.3 \mathrm{MPN} / \mathrm{mL}$ \\
Boiled chicken & 3 & 0 & $<0.3 \mathrm{MPN} / \mathrm{g}$ \\
Chopped chicken & 2 & 1 & $0.3 \mathrm{MPN} / \mathrm{g}$ \\
Cutting board & 3 & 1 & $0.3 \mathrm{MPN} / 25 \mathrm{~cm}^{2}$ \\
Hand & 3 & 2 & $0.3 \mathrm{MPN} / \mathrm{Hand}$ \\
Seasoning & 3 & 3 & $0.8-0.92 \mathrm{MPN} / \mathrm{g}$ \\
Sauced chicken & 6 & 2 & $0.74-1.1 \mathrm{MPN} / \mathrm{g}$ \\
\hline \multicolumn{4}{c}{ Total } \\
\hline $\mathrm{t}_{\text {boiling }}=25 \mathrm{~min} ; \mathrm{T}_{\text {meat core }}=78.5^{\circ} \mathrm{C} ; \mathrm{t}_{\text {frying }}=8 \mathrm{~min} ; \mathrm{T}_{\text {meat }}$ core $=$ \\
$96^{\circ} \mathrm{C}$.
\end{tabular}

Groundwater and municipal water were used in the cooking process, but only groundwater was contaminated by Salmonella spp. The prevalence of Salmonella contamination in water was $23.5 \%$ (4 of 17 samples) and higher than the report from Momtaz et al. (2013) which was $0.89 \%$ in Iran. Groundwater was well known as a source of Salmonella Enteritidis (Kovacic et al., 2017) and also the carrier of typhoidal Salmonella serovar (Levantesi et al., 2012).

Another material used in chicken side dishes processing was eggs. Eggs were used in breaded fried chicken processing and contaminated by $0.92 \mathrm{MPN} / \mathrm{g}$ of Salmonella spp. Contamination in egg in Indonesia was reported by Chusniati et al. (2009) who found Salmonella spp. in $5.56 \%$ of 36 egg samples. It was higher than reported by Singh et al. (2010). The results showed that contamination of Salmonella spp. in eggs was $4.82 \%$, with lower incidence in farms samples. Furthermore, they obtained 27 isolates that included $S$. Typhimurium (55.5\%), S. Lagos, $S$. Africana, and Salmonella II. Kouam et al. (2018) studied Salmonella spp. contamination of 140 eggs from 19 farms. All farms sample contain at least one type serovar of Salmonella spp.

Another possible source of Salmonella spp. in sauced chicken processing was cutting board and hand of food handlers. Two of seven swab samples of hands and one of 4 swab samples of the cutting board was contaminated by Salmonella spp. The level of contamination by Salmonella spp. was $0.3 \mathrm{MPN} / \mathrm{hand}$ and $0.3 \mathrm{MPN} / 25 \mathrm{~cm}^{2}$ respectively. Gorman et al. (2002) reported that Salmonella could be isolated from the counter's surface where food was processed and from aprons used by food handlers with a prevalence of $16.6 \%$ from total samples. Salmonella spp. can survive in a dry environment for a long time (Humphrey et al., 1994). Salmonella Enteritidis PT4 has also been reported showing the ability to form biofilms on the stainless-steel surface. These bacteria could grow in the presence of invisible leftover on the surface of the utensils as a result of inadequate washing process as reported by Giaouris and Nychas (2006).

In this study, all food handlers used frying method where only half of the chicken submerged in the oil. Although the temperature reached a high point, the possibility of uneven heat over the meat make Salmonella spp. could be recovered. Roccato et al. (2014) studied the resistance of Salmonella Typhimurium DT 104 in chicken-based foods with 3 cooking method, namely frying, grilling and baking. The results showed that 26 of 78 samples were contaminated and the highest prevalence came from frying method (12 positive samples), followed by grilling and baking. The average temperature of chicken meat during the frying process was $59-74^{\circ} \mathrm{C}$. He et al. (2011) reported that Salmonella spp. could be eliminated when the internal temperature of food reached more than $72^{\circ} \mathrm{C}$ during the processing. It could reduce Salmonella spp. into 2 logs, 
but the temperature of $90^{\circ} \mathrm{C}$ could reduce the number into 5.5-7.1 log. Evans et al. (1996) reported that Salmonella Enteritidis PT 4 in beef rissoles was not eliminated during the frying process on $142-157^{\circ} \mathrm{C}$ for 57 minutes. This bacterium came from eggs that were one of the ingredients. Beef rissoles were assumed as cooked when floating in the oil. It turns out the inside temperature was only $48-60^{\circ} \mathrm{C}$ while the external temperature was $91-95^{\circ} \mathrm{C}$.

Heat resistance of Salmonella is different in each serovar, influenced by genetic factors, environmental conditions, and adaptability. Pre-exposure to thermal treatment on precooking could increase survival ability in thermal treatment such as frying. Chen et al. (2013) found Salmonella Senftenberg could survive in the chicken litter for $24 \mathrm{hrs}$ at $80^{\circ} \mathrm{C}$. A similar report from de Jong et al. (2012), chicken breast fillet inoculated by Salmonella Typhimurium was boiled, and after one minute the temperature of the chicken became $85^{\circ} \mathrm{C}$. Extreme reduction on Salmonella Typhimurium has seen in $2.20 \mathrm{~min}$, but even after $10 \mathrm{mins}$ of boiling the bacteria could still be recovered. In this study, the decreasing of Salmonella was detected in all food processing chains. However, Salmonella spp. was still recovered in some of the end products, except in fried chicken with precooking.

\section{Conclusion}

The pre-cooking step in the selected processing chain of chicken-based side dishes reduced Salmonella spp. to an undetectable level. The occurrence of Salmonella spp. in 4 of 30 end product samples likely associated with cross-contamination. Inadequate deepfrying practices by all food handlers probably also contributed to the survival of Salmonella. This study suggested the need for education of the food handlers on proper cooking to improve the safety of the food.

\section{Conflict of Interest}

The authors declare no conflict of interest.

\section{Acknowledgments}

The authors thank to the Directorate of Food Safety Surveillance and Extension (SPKP) and Research Centre for Drug and Food (PROM) of the National Agency of Drug and Food Control (BPOM) in the Republic of Indonesia for providing financial assistance for this research.

\section{References}

Alali, W.Q., Gaydashov, R., Petrova, E., Panin, A.,
Tugarinov, O., Kulikovskii, A., Mamleeva, D., Walls, I. and Doyle, M.P. (2012). Prevalence of Salmonella on Retail Chicken Meat in Russian Federation. Journal of Food Protection, 75(8), 1469 -1473. https://doi.org/10.4315/0362-028X.JFP-12080

Barua, H., Biswas, P.K., Talukder, K.A., Olsen, K.E.P. and Christensen, J.P. (2014). Poultry as a possible source of non-typhoidal Salmonella enterica serovars in humans in Bangladesh. Veterinary Microbiology, 168(2-4), 372-380. https://doi.org/10.1016/ j.vetmic.2013.11.020

Cary, J.W., Linz, J.E. and Bhatnagar, D. (2000). Microbial Foodborne Disease: Mechanisms of Pathogenesis and Toxin Synthesis, p. 3-12. UK: CRC Press.

Chen, Z., Diao, J., Dharmasena, M., Ionita, C., Jiang, X. and Rieck, J. (2013). Thermal Inactivation of Desiccation-Adapted Salmonella spp. in Aged Chicken Litter. Applied and Environmental Microbiology, 79(22), 7013-7020. https:// doi.org/10.1128/AEM.01969-13

Chusniati, S., Budiono, Nelson, R., Kurnijasanti and Rochmah. (2009). Detection of Salmonella sp. in Local Eggs Used to Added to Traditional Herbal Drink (Jamu) In Sidoardjo. Journal of Poultry Science, 2(1), 20-23.

Cobet, A.B., Gershman, M., Moechtar, M.A., Sumarno and Sunoto. (1981). Salmonellosis in Indonesia: phage type of Salmonella oranienburg obtained from hospitalized patients in Jakarta, Indonesia. The Journal of Hygiene, 86(2), 227-236. https:// doi.org/10.1017/S0022172400068959

de Jong, A.E.I., van Asselt, E.D., Zwietering, M.H., Nauta, M.J. and de Jonge, R. (2012). Extreme Heat Resistance of Food Borne Pathogens Campylobacter jejuni, Escherichia coli, and Salmonella Typhimurium on Chicken Breast Fillet during Cooking. International Journal of Microbiology, 2012, 1-10. https://doi.org/10.1155/2012/196841

El-Aziz, D.M.A. (2013). Detection of Salmonella Typhimurium in retail chicken meat and chicken giblets. Asian Pacific Journal of Tropical Biomedicine, 3(9), 678-681. https://doi.org/10.1016/ S2221-1691(13)60138-0

Evans, M.R., Hutchings, P.G., Ribeiro, C.D. and Westmoreland, D. (1996). A hospital outbreak of Salmonella food poisoning due to inadequate deepfat frying. Epidemiology and Infection, 116(2), 155160. https://doi.org/10.1017/S0950268800052389

Galán, J.E. and Curtiss, R. (1989). Cloning and molecular characterization of genes whose products 
allow Salmonella typhimurium to penetrate tissue culture cells. Proceedings of the National Academy of Sciences of the United States of America, 86(16), 6383-6387. https://doi.org/10.1073/pnas.86.16.6383

Giaouris, E.D. and Nychas, G.J.E. (2006). The adherence of Salmonella Enteritidis PT4 to stainless steel: The importance of the air-liquid interface and nutrient availability. Food Microbiology, 23(8), 747-752. https://doi.org/10.1016/j.fm.2006.02.006

Gorman, R., Bloomfield, S. and Adley, C. (2002). A study of cross-contamination of food-borne pathogens in the domestic kitchen in the Republic of Ireland. International Journal of Food Microbiology, 76(1-2), 143-150. https://doi.org/10.1016/S01681605(02)00028-4

Gould, L.H., Walsh, K.A., Vieira, A.R., Herman, K., Williams, I.T., Hall, A.J., Cole, D., Centers for Disease Control and Prevention [CDC]. (2013). Surveillance for foodborne disease outbreaks United States, 1998-2008. The Morbidity and Mortality Weekly Report Surveillance Summaries, 62 (2), 1-34.

Hajrawati, Fadliah, M., Wahyuni and Arief, I.I. (2016). Physical, Microbiology, dan Organoleptic of Chicken Meat in Traditional Markets of Bogor. Jurnal Ilmu Produksi dan Teknologi Hasil Peternakan, 4(3), 386-389. https://doi.org/10.29244/ jipthp.4.3.386-389

He, Y., Guo, D., Yang, J., Tortorello, M.L. and Zhang, W. (2011). Survival and Heat Resistance of Salmonella enterica and Escherichia coli $\mathrm{O} 157: \mathrm{H} 7$ in Peanut Butter. Applied and Environmental Microbiology, 77(23), 8434-8438. https:// doi.org/10.1128/AEM.06270-11

Humphrey, T.J., Martin, K.W. and Whitehead, A. (1994). Contamination of hands and work surfaces with Salmonella enteritidis PT4 during the preparation of egg dishes. Epidemiology and Infection, 113(3), 403-409. https://doi.org/10.1017/ S0950268800068412

Kang, M.S., Oh, J.Y., Kwon, Y.K., Lee, D.Y., Jeong, O.M., Choi, B.K., Youna, S.Y., Jeon, B.W., Lee, H.J. and Lee, H.S. (2017). Public health significance of major genotypes of Salmonella spp. enterica serovar enteritidis present in both human and chicken isolates in Korea. Research in Veterinary Science, 112, 125-131. https://doi.org/10.1016/ j.rvsc.2017.02.010

Kholifah, L.N., Dharma, B. and Situmeang, R. (2016). Detection of Salmonella contamination on poultry meat at slaughterhouses and traditional markets using compact dry method in Samarinda City presented at the Proceedings of FMIPA Unmul's
Science and Technology Seminar, p. 383-387. Samarinda: Unmul.

Kouam, M.K., Biekop, M.H.F., Katte, B. and Teguia, A. (2018). Salmonella status of table eggs in commercial layer farms in Menoua Division, West region of Cameroon. Food Control, 85, 345-349. https://doi.org/10.1016/j.foodcont.2017.09.037

Kovacic, A., Huljev, Z. and Susi, E. (2017). Ground water as a source of an outbreak of Salmonella Enteridis. Journal of Epidemiology and Global Health, 7(3), 181-184. https://doi.org/10.1016/ j.jegh.2017.05.001

Levantesi, C., Bonadonna, L., Briancesco, R., Grohmann, E., Tozed, S. and Tando, V. (2012). Salmonella in surface and drinking water: Occurrence and water-mediated transmission. Food Research International, 45(2), 587-602. https:// doi.org/10.1016/j.foodres.2011.06.037

Maulita, R., Darniati and Abrar. (2017). Total of Salmonella sp. contamination in poultry cutting equipment at the Lamnyong market. Jurnal Ilmiah Mahasiswa Veteriner, 1(3), 504-512.

Momtaz, H., Dehkordi, F.S., Rahimi, E. and Asgarifar, A. (2013). Detection of Escherichia coli, Salmonella species, and Vibrio cholerae in tap water and bottled drinking water in Isfahan, Iran. Biomed Central Public Health, 13(556), 1-7. https:// doi.org/10.1186/1471-2458-13-556

Naik, V.K., Shakya, S., Patyal, A., Gade, N.E. and Bhoomika. (2015). Isolation and molecular characterization of Salmonella spp. from chevon and chicken meat collected from different districts of Chhattisgarh, India. Veterinary World, 8(6), 702706. https://doi.org/10.14202/vetworld.2015.702-706

NADFC (National Agency of Drug and Food Control). (2012). Serving Guidelines of Ready to Eat Food and Household Food Industries. Directorate of Food Safety Surveillance and Extension. Jakarta: NADFC

NADFC (National Agency of Drug and Food Control). (2016a). Quantitative analysis of Salmonella in fried chicken by Most Probable number and PCR confirmation. Research Center of Drug and Food. Jakarta: NADFC

NADFC (National Agency of Drug and Food Control). (2016b). Regulation of the Head of National Agency of Drug and Food Commission Number 16 of 2016 Concerning Microbiological Criteria in Processed Food. Jakarta: NADFC

NADFC (National Agency of Drug and Food Control). (2017). Annual Report. Jakarta: NADFC

Nidaullah, H., Abirami, N., Shamila-Syuhada, A.K., Chuah, L.O., Nurul, H., Tan, T.P., Abidin, F.W.Z. 
and Rusul, G. (2017). Prevalence of Salmonella in poultry processing environments in wet markets in Penang and Perlis, Malaysia. Veterinary World, 10 (3), 286-292. https://doi.org/10.14202/ vetworld.2017.286-292

Pavic, A., Groves, P.J., Bailey, G. and Cox, J.M. (2009). A validated miniaturized MPN method, based on ISO 6579:2002, for the enumeration of Salmonella from poultry matrices. Journal of Applied Microbiology, 109(1), 25-34. https:// doi.org/10.1111/j.1365-2672.2009.04649.x

Punjabi, N.H., Agtini, M.D., Ochiai, R.L., Simanjuntak, C.H., Lesmana, M., Subekti, D., Oyofo, B.A., von Seidlein, L., Deen, J., Shin, S., Acosta, C., Wangsasaputra, F., Pulungsih, S.P., Saroso, S., Suyeti, Suharno, R., Sudarmono, P., Syarurachman, A., Suwandono, A., Arjoso, S., Beecham III, H.J., Corwin, A.L. and Clemens, J.D. (2013). Enteric fever burden in North Jakarta, Indonesia: a prospective, community-based study. Journal of Infection in Developing Countries, 7, 781-787. https://doi.org/10.3855/jidc.2629

Rahn, K., De Grandis, S.A., Clarke, R.C., McEwen, S.A., Galan, J.E., Ginocchio, C., Curtiss III, R. and Gyles, C.L. (1992). Amplification of an invA gene sequence of Salmonella Typhimurium by polymerase chain reaction as a specific method of detection of Salmonella. Journal of Molecular and Cellular Probes, 6(4), 271-279. https:// doi.org/10.1016/0890-8508(92)90002-F

Roccato, A., Uyttendaele, M., Cibin, V., Barrucci, F., Cappa, V., Zavagnin, P., Longo, A. and Ricci, A. (2014). Survival of Salmonella Typhimurium in poultry-based meat preparations during grilling, frying and baking. International Journal of Food Microbiology, 197, 1-8. https://doi.org/10.1016/ j.ijfoodmicro.2014.12.007

Singh, S., Yadav, A.S., Singh, S.M. and Bharti, P. (2010). Prevalence of Salmonella in chicken eggs collected from poultry farms and marketing channels and their antimicrobial resistance. Food Research International, 43(8), 2027-2030. https:// doi.org/10.1016/j.foodres.2010.06.001

van Doren, J.M., Neil, K.P., Parish, M., Gieraltowski, L., Gould, L.H. and Gombas, K.L. (2013). Foodborne illness outbreaks from microbial contaminants in spices, 1973-2010. Food Microbiology, 36(2), 456464. https://doi.org/10.1016/j.fm.2013.04.014 